\title{
The Forerunners
}

\section{Author(s): Vernon Blackburn}

Source: The Musical Times and Singing Class Circular, Vol. 43, No. 713 (Jul. 1, 1902), pp. 455-457

\section{Published by: Musical Times Publications Ltd.}

Stable URL: http://www.jstor.org/stable/3369666

Accessed: 12-05-2016 05:16 UTC

\footnotetext{
Your use of the JSTOR archive indicates your acceptance of the Terms \& Conditions of Use, available at

http://about.jstor.org/terms
}

JSTOR is a not-for-profit service that helps scholars, researchers, and students discover, use, and build upon a wide range of content in a trusted digital archive. We use information technology and tools to increase productivity and facilitate new forms of scholarship. For more information about JSTOR, please contact support@jstor.org.

Musical Times Publications Ltd. is collaborating with JSTOR to digitize, preserve and extend access to The Musical Times and Singing Class Circular 
Thomas Tallis. Some of the quaint designations of the pieces may be given:-

\section{Sermone Blando.}

Filliday Floutes me.

The Galliard to Doct. Bulle's Fantastick Pavin.

The Quadren Pavin.

The Galliard to it.

A Fancy for a Double Orgaine

Docter Bulle's Jewell.

There is also 'A Catch of 9 parts in one,' set to the words 'Let us goe pray for John Cook's soul.' *

A fine folio volume in the autograph of Henry Purcell arouses special interest. An old manuscript catalogue of the Royal Music Library, compiled about the year I 780 , says of this book: - This volume is Purcell's original score of several of his anthems and odes, and was presented by Dr. Philip Hayes.' This magnificent tome, which bears upon its first page the signature of 'E. H. Purcell, grandson of the author of this Book,' is entitled 'A Score Booke containing severall anthems $w^{\text {th }}$ Symphonies.' The anthems are at one end, and at the other are "Welcome Songs and other songs, all by my father,' as the only surviving son of the composer therein recorded. Among the anthems, all of which have accompaniments for strings, is 'My heart is inditing' (8 voices), ' one of $\mathrm{y}^{\mathrm{e}}$ anthems sung at $\mathrm{y}^{\mathrm{e}}$ coronation of James II.' Two anthems have obbligati for two violins. We find in this book such a direction as ' the triple of the symphony again,' and as a title, 'Symphony $w^{\text {th }} 2$ Trumpits, 2 Violins, a Tenur and Bass.' The inscriptions on some of the 'Welcome Songs,' \&c., speak for themselves.

A Welcome Song for his Royal Highness on his return from Scotland, yeare 1682 .

A Welcome Song for his Majesty on his return from Newmarket, Oct. ye 21, I682.

A Latine Song made upon St. Cecilia, whose day is commemorated yearly by all Musitians, made in ye year 1683 .

Sighs for our late Sov'raiyn King Charles ye $2^{\mathrm{d}}$.

A Song that was perform'd at Mr. Maidwell's, a schoolmaster, on ye $5^{\text {th }}$ of August, I689, ye words by one of his scholars.

Next to the Handel autograph scores this Purcell autograph volume is one of the most precious in the Royal Music Library.

The 3,000 volumes of which, roughly speaking, the Library consists include many modern publications - e.g., complete editions of the great classical composers, and an entire set of Wagner's operas in full score, a most valuable acquisition; thus the ancient and modern productions of the art find a home in this Royal collection. Many of the books, presentation copies of feeble effort, are, however, of little value, notwithstanding their gorgeous bindings.

* Full descriptions of these and other Virginal Collections of Music from the able pen of Mr. W. Barclay Squire, will be found in Grove'
For kind help rendered in the preparation of these inexhaustive remarks on the King's Music Library, thanks are due to Mr. Barclay Squire, and in no small degree to Sir Walter Parratt, Master of the King's Musick, for his kindness in many ways.

The next article of this series will treat of music in the Bodleian Library, Oxford, which is to celebrate its Quincentenary in the month of October next.

\section{THE FORERUNNERS.}

The fate of all pioneers belongs to somewhat of a tragedy, no less in art than in active life. Amerigo was the forerunner of Columbus ; and although his name has been perpetuated in the histories as the man who gave his name to the New World, the romance of Columbus has, nevertheless, occupied most of the ideas of human kind in its remembrance of the great discovery. Now, Art is a more remote province than a mere geographical conquest; and it is therefore most reasonable (though infinitely pathetic) to find that in art the cruelty which attends the career of the ancestry of things seems even more acute than that which goes side by side with mere physical discoveries. Copernicus, for example (to take a scientific instance), discovered the relations between planetary movements and cube-roots. Surely that was a most amazing matter to diagnose. The man in the street, however, knows nothing of planetary movements, or of cube-roots; yet he knows everything about the laws of gravitation. Mark then the sequel. Sir Isaac Newton discovered the laws of gravitation from the data furnished by Copernicus. Newton remains for ever as the ideal of human genius; but how few remember the influences which provided him with his material? One may say, of course, that every locus represented by an equation of the second degree is either a parabola, a hyperbola, or so forth; but of what effect is that to the average man? He skims the words over; he yawns; he mutters 'pedantry'; and he never suspects that what are to him the commonplace things of life are the outcome of such cabalistic terms.

Music is the counterpart of mathematics in so many points that it is not wonderful that it, too, has had an ancestry which is largely buried in neglect. Music may be described as mathematics transformed by a fairy-wand into a figure of glory. An ellipse made silvern, two straight lines converted into 'golden rules'-you might continue the list indefinitely-but herein lies the essence of its effectiveness. And who were the forerunners? Who were they who snatched from the night some principles of art, and some such sense of fine combination, as in the end has produced the magnificent body of latter-day music which we recognize as fulfilling in a peculiar sense the emotion of the time? One asks the question in vain. You look abroad and find 
only such traces as persuade you of no more than their mere existence. You are in a historical mood, haply; and you read with glow and admiration 'Summer is icumen in.' Then you ask, somewhat dismally: 'Whence came this particular art ?' Here is clearly no forerunner. The thing seems complete in itself. It represents no beginning. Its complex beauty, its most definite self-assertion, make no appeal whatever to the future. It is a summary, not a timid suggestion; it is rather posterity than ancestry. It has had a forerunner all its own, and yet is a forerunner itself.

It is only after such a revelation that one begins to search the facts that lie actually under one's eyes. (By such a method, it may be said, and by it alone, have all the great scientific discoveries been made.) Treading cautiously, you watch in your advance the panoramic figures of Time as they stepped vividly in their own day. Here is Gluck. He is not attractive at a first glance; he has no particular love for strangers; he is curiously inaccessible. There approaches one Dr. Burney, who has braved extraordinary perils by land and by water in order to see the great composer. $\mathrm{He}$ plays 'Orfeo' to the English musician; and thenand then-he fades into space; and in his place there swims up a face resolute and most determined, a face upon which Gluck has cast his shadow-one ready, you would say, for every onslaught, and for every chance and change of time. Looking back upon the ideals of Gluck, this face is contemplative, and turns to both a backward and a forward issue. It is the face of Richard Wagner. Here is one, you would say, who, above all men, has the power of piercing the future. It was his attribute, even in his own day, to be known as the musician of the future. And yet one sees him looking back and facing his forerunner with most attentive zeal. Gluck had formulated in one of his famous prefaces his dramatic ideal. Wagner took the thing up and multiplied it fourfold. The forerunner had not worked in vain; he had created Wagnerism, and had yet completed a wonderful work in itself.

Let me go back somewhat in history. The men whose musical work is identified (far more in the character of collector and annotator than in that of composer) with the name of Gregory the Great were certainly the forerunners, in the strictest sense of the term, of much foreign mediæval musical art. They amassed a body of melody; they discovered how to express their religious belief in a single line; they lamented for their dead in music; they celebrated ideally the 'marriage of true minds'-note their 'Veni, Sponsa Christi'; they sang hymns of war in warrior tones - 'Deus tuorum militum'; they cried 'amore langueo' with an inimitable sense of repose and of languishment; they were, in fact, in their own way, the interpreters of human emotion, from a superficial aspect of things, as wonderful as one can conceive. Sometimes I think that ancient Egypt, as one sees it through its dim and faint records, had some such musical vitality, and that the most wonderful nation of past days compiled its qualities in a musical outburst of thought. How great a forerunner is here! Here is a nation teaching Judaism how to sing. 'In Exitu Israel de Egypto'-the hymn which has been termed 'Modus Peregrinus' -was surely learned from the nation who understood the weariness of the flesh, who knew well how brief were the days of this life, and who, rather than die for ever, made mummies of men, and kept dead things in an inanimate condition of existence, sooner than relinquish the thought of resurrection. And there is no doubt that Judæa, the persistent, learned the Egyptian lore ; there is no doubt that the chants and the songs which the Jews have handed on to us came from Egypt. Here was indeed a forerunner of the world, as I have just now said; and I fancy that in this modern civilization of ours it will not be easy to find so curious an example of the temporal ancestry of things which fulfil, at the present day, a complete vision of an Art.

I have elaborated as far as is necessary the principle which seems to run through all artistic endeavour. That endeavour must be preceded by a paternal effort. The father, the son, the grandson, may not reach the kingdom which was originally marked out for their possession; and yet, in the final issue, the forerunners win their crown. They, in their lifetime, had no reward; they had no recognition. They stepped into the darkness surely with a sense of failure upon their souls, even as Moses, looking from the hill whereon he drew his last sigh, gazed upon the promised land knowing that he would never enter upon the fruition of its glories. But we who look back upon lives fulfilled can see that the forerunners are greatly to be admired. Purcell is, perhaps, an exception in some measure. $\mathrm{He}$ certainly had applause in his own day; but the applause was not approachable to his genuine merit. Yet he forecast Wagner-the artist who founded Bayreuth, and was the favourite of a King; he forecast him so curiously that, in a certain passage of 'King Arthur,' you have Wagner, in considering precisely a similar situation, using the same phrases, the same harmonies, the same orchestration (essentially, and, of course, within limits) as those invented by Purcell. Let nobody for one moment think that Wagner was therefore in any sense one who at any time depended upon another man's idea for purposes of his own creation. My point is rather this, that Purcell was a forerunner in so far that his absorption of musical ideas in his own day was so complete that, in the passage of time, the new musician adopted a phrase as natural which had to the older master doubtlessly appealed as a singularly bold and original idea. In other words, the forerunner had conquered a province; he had made novelty a commonplace; he had accomplished his mission.

I have it in my heart, then, to be sad for many of the forerunners of music. They look ahead; 
they are on tip-toe, peering into the future. They push the abysm of time (as it were) away from their feet; and they mount upwards, but they faint because Time is cruel to them, and will not grant them a lease wherein to fulfil their ideals; but Time, relenting, gives the heritage over to another of a later period, and he reaps the reward which the dead had hoped to attain. It is something of a heart-rending thought; but it is so universal in the commoner walks of life, that one is almost surprised to find the same law working out to what seem to be more important issues in the life that is naturally regarded as more chosen and as more separate.

With all the temptations to emotionalism that music contains, this art more than any seems to me to contain eternal seed-qualities which make for future repute, for future appreciation. One may have, at this moment, it may be, many controversial enemies; that is neither here nor there; it is in the nature of things. But one still watches the passage of music along a path which no words can oppose with any effectual effort :-

Quod non imber edax, non Aquilo impotens

Possit diruere.

One sees the advance of things through the forecasts which belong to a dead generation. Those forerunners (I will not doubt it) did not think that they had come to the end of their art. They were but groping their way. They found the milestones on their path, and, as one might do in a country lane, they left their bunch of wild flowers behind them, as they journeyed forward. Nevertheless, they did their work; and very often it happened that their work in itself was of a most remarkable quality. Their chief accomplishment, however, seems to have been to delve a path for the generations that were then only in the making. How strange a problem is thus set before the imagination! They were the forerunners of our art; and we, standing upon a mere bridge of time, dismiss them with a backward gesture, feeling our own imperturbable finality in musical phraseology. We see the receding bridges, it is true, but do we herald, even in idea, the on-coming tidal rush of the future? Richard Strauss, for example, makes no secret of his visitations into the house of the future. To him, as to all his companions in the past, it has occurred that he has been belaboured with abuse, that his work has been pronounced impossible, and outside all decent consideration. Richard Strauss, under one's contemporary eyes, may be developing into the position of a forerunner.

The cemeteries which contain the ashes of great men seldom find a last resting-place for the relics of those who, stepping high upon the ladder of the present, look forward to the triumphs of the future. The more primitive forerunners of music lack recognition. They are treated as the necessary begetters of modern musical thought, not as the splendid adventurers who made modern musical thought a possible thing. Yet they were the guessers of musical life; they spoke of the
' music of the spheres' - feeling in some grandiosely uncertain way that music existed throughout the Kosmos. Not for them was rule or definite law. They imagined greatly; and the lesser generations that came along captured their big ideas, put them into shape and form, and made them intelligible to this most unintelligible race of man. It is for that reason that one can ascend, generation by generation, and find that the forerunners of our immediate times were, indeed, men of most deserved repute, who stood only at the outset of the cycle later to be completed. We have a very great pride in our modernity; and we have reason. But the modernity of yesterday was no less vain. The savage that drummed upon stretched skins thought himself extremely modern; but to-day we laugh at his miserable drum. Yet was he, no less than Gluck, than Wagner, than Richard Strauss a-forerunner. Let it not be thought for a moment that one cares not for any forerunners any artistic generation. 'Homo sum,' said Terence; and I belong to my time also. One does but draw a parallel - here and there burlesque, it is true; but anybody who has the purpose to be philosophic may do something to help human thought and human endeavour.

Vernon Blackburn.

\section{MORLEY'S PLAINE AND EASIE INTRODUCTION TO PRACTICALL MUSICKE.}

Passages from a Lecture Delivered by the late Sir John Stainer, Professor of Music, to the University OF OXFord; December 8, I897. The TERCENTENARY OF THE YeAR IN WHICH MORLEY'S BOOK WAS PUBLISHED (I597).

No book of musical instruction is so worthy of commemoration on its tercentenary as this by old Thomas Morley. He was born in 1557 when Palestrina was between twenty and thirty years of age, he was a contemporary of Wilbye, Weelkes, Dowland, Converso, and Marenzio. Monteverde had not yet stood forth as the champion of an advanced style.

Morley had studied assiduously the compositions of former generations - those of Dunstable, Fulda, Josquin, Ockenheim, Mouton, Horatio Vecchio, Tallis, Kirby, and others, and he was a pupil of our great Englishman, Bird, who was his senior by about twenty years and yet survived him by nearly twenty years. It is necessary to bear this in mind, and throw ourselves back into the midst of his entourage, in order to gauge correctly his true position in the history of the art of music. His early musical training was probably received when a choristerboy of St. Paul's Cathedral, of which he afterwards became organist, but he resigned this post and kept his appointment as a gentleman of the Chapel Royal.

This introduction to practical music which survives as a permanent monument of his learning and genius was written when he was forty years of age. Seven years later he was 